\title{
ハーブによる疫病防除の試み（V） 養液栽培におけるセリ混植の効果
}

\author{
宮田善雄・行藤とし子 \\ (京都府立大学農学部)
}

各種作物の根腐れ性疫病の防除手段のひとつとし て，ハーブを間作あるいは混作することの有効性につ いてはすでに報告した ${ }^{1)}$ ○回はさらに養液栽培への 適用について, 数種のハーブ植物や水田雑草について スクリーニングを行い, 効果の期待されるセリについ て簡単な養液栽培装置を用いて実用化試験を行った。

\section{材料および方法}

供試植物は市販のハーブ類と野外で採取した水田雑 草類を用いた。これらはバーミキュライトで插し木に より育てた苗, あるいは野外より採取した幼植物で, いずれも根をよく洗った後, 石英砂あるいはクレイ ボールをベッドとして小型養液栽培容器で養液栽培し た。養液は春日井氏液 ${ }^{2}$ あるいは市販養液 (野菜用八イ ポネックス， 8-12-6) を用いた。栽培はガラス温 室あるいは植物育成箱内で行った。供試菌はPhytophthora capsici（SMF 651 あるいは CAF 921）で, 菌 糸ひも法に準じてニンジンジュース遠沈上清培地で培 養し, 必要に応じて $\mathrm{MCZ}$ 液中で遊走子囊を形成させ た上, 疫病菌選択培地 (RHIRo一-90) を用いて検定し だ。

\section{供試植物の養液栽培と疫病菌抑制効果}

\section{1 ）ハーブ植物類の場合}

最初に, 前回の試験から効果の期待された幾つかの ハーブ類について, 水栽培を行い, その栽培濾液につ いて菌系ひも検定を試みた結果では，パイナップルミ ント，オーデコロンミント，レモンバームなどは，水 中での発根性などは比較的良好で, ある程度 （60～70\%）の疫病抑制効果が認められた。しかし， これらを養液栽培に移すと根の伸長が著しく抑制さ れ，水耕への適用は難しいと判断された。

2 ) 水田雑草類の場合

付属農場の水田の湿潤状態下で生育している雑草, コナギ, キカシグサ, ミズタガラシ, セリなどを採取 し, まず，水栽培して，その培養濾液について疫病菌 抑制効果を検定した。その結果, セリ（第 2 図）は遊 走子囊形成を著しく抑制した。また，コナギ(第 1 図) にもかなりの遊走子囊形成能の抑制が認められた。そ
の他の雑草類では抑制はなく，むしろ促進される場合 がみられた。つぎに，これらの植物を養液栽培（ハイ ポネックス 1000 倍液)に移したところ, セリはやや生 育が劣る程度であったが，他はいずれもかなり不良と なった（第 1 図）。コナギは 2000 倍液（通常の $1 / 2$ 濃度) になるとわずかに新根の伸長が認められたが, キカシグサ，ミズタガラシではなおきわめて不良で あった。これらの植物を $\mathrm{N}, \mathrm{P}, \mathrm{K}$ 成分についてのみ濃 度を変更した養液 (春日井養液) 中で栽培したところ, 生育不良は主としてN成分によるものであることが 解った。これらの供試植物は, ほとんど野生に近い性 質を残しているために，養分の豊富な状態を好まない のであろう。このことはこれら水田雑草類の水田養分 の収奪は考えられているほどに大きなものではないこ とを意味しているのかも知れない。

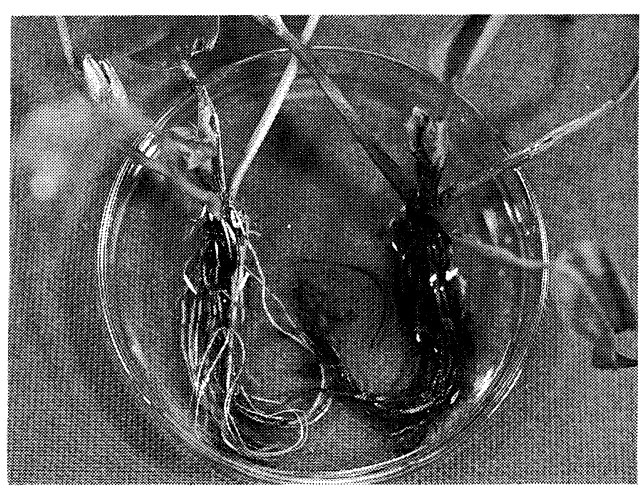

第 1 図 コナギの養液中における根の生育不良（右）

\section{セリの養液栽培と疫病抑制効果}

農場用水路からセりを採取し, 分株して, 1 週間ほ ど水栽培した後，小型養液栽培装置（第 2 図）を用い てハイポネックス 2000 倍液中で栽培した。1 週間毎に 養液を採取し，その疫病菌抑制能を測定したところ， 3 週間後にほぼ完全に遊走子囊形成を抑制する状態に 達した。そこで，セリ栽培区と無栽培区に，別に育成 したキュウリ苗を移植し，疫病菌々糸断片懸濁液を養

Yoshio MiYata and Toshiko Yukito (Fac. Agr., Kyoto Pref. Univ.) Biological Control of Phytophthora Diseases by Herb Plants (V) Seri, a Oenanthe Plant for the Control of Phytophthora Disease in Water Culture. 


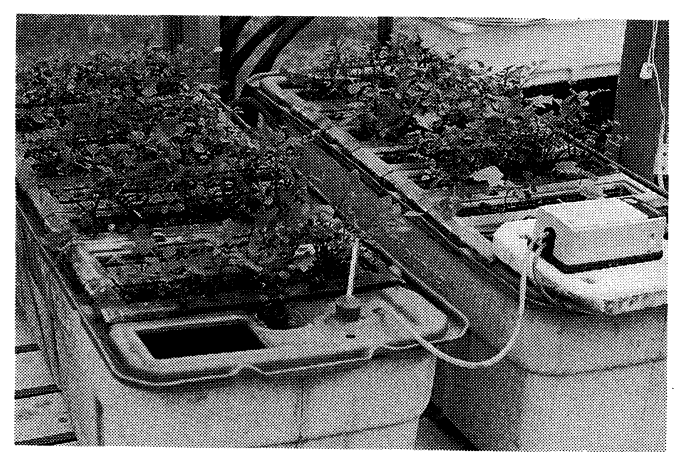

\section{第 2 図 セリ混植による養液栽培キュウリの疫病 防除試験（小型実験用養液栽培装置）}

液タンク内に接種して, 栽培を続けた。 2 週間後, 根 を検査し, その褐変状態などにより発病を比較したと ころ, セリ栽培区ではほとんど褐変が認められなかっ たのに対し, 無栽培区ではすべての株で根の褐変がみ
第 1 表 水田雑草栽培養液の疫病菌抑制効果

\begin{tabular}{lrrrr}
\hline \hline & \multicolumn{4}{c}{ 遊走子裳形成数 } \\
\cline { 2 - 5 } & \multicolumn{1}{c}{1} & \multicolumn{1}{c}{2} & \multicolumn{1}{c}{3} & \multicolumn{1}{c}{ 平均 } \\
\hline コナギ & 16.7 & 39.8 & 32.0 & 29.5 \\
セ リ & 0.8 & 7.3 & 6.3 & 4.8 \\
無栽培 & 109.3 & 106.7 & 86.7 & \multicolumn{1}{c}{100.9} \\
\hline 数値は菌系ひも $10 \mathrm{~mm}$ 当りの遊走子囊形成数
\end{tabular}

られ，軟化腐敗に達しているものもあった。

以上のことから, 養液栽培においても, ハーブの一 種セリを混植することによって, 疫病の発生を抑制す ることの可能性が示された。さらに本格的な養液栽培 施設において実地試験する予定である。

\section{関連文献}

1 ）宮田善雄・池川佐保子（1992）関西病虫研報 34 : $83-84$.

2 ) 植物栄養学実験編集委員会編（1959）植物栄養学 実験, 朝倉書店：309. 